\title{
POLISH PEASANTS IN EASTERN GALICIA: INDIFFERENT TO THE NATION OR PILLARS OF POLISHNESS? NATIONAL ATTITUDES IN THE LIGHT OF JÓZEF CHAŁASIŃSKI'S COLLECTION OF PEASANT YOUTH MEMOIRS
}

\begin{abstract}
The following article will discuss Polish national attitudes among peasants in Eastern Galicia in the light of memoirs of peasant youth that the sociologist Józef Chałasiński collected in 1938 and analysed in his seminal work Mtode pokolenie chtopów [The young generation of peasants]. ${ }^{1}$ It will start with a discussion of differences in processes of the integration of peasants into the Polish nation in Western and Eastern Galicia until WWI. The article will argue that Western Galician peasants, represented in the Polish peasant parties, embraced the idea of being the 'pillars of Polishness' while for Roman Catholic or Polish speaking peasants in Eastern Galicia that remained rather an ascription by nationalist circles of the Polish intelligentsia. This condition, as Józef Chałasiński's collection of memoirs show, does not seem to have changed much during the interwar period.
\end{abstract}

Keywords: Eastern Galicia (Ukraine), Józef Chałasiński, peasantry, national identity, Polish peasant movement.

\section{I \\ INTRODUCTION}

In recent years many important studies have been published on national attitudes among peasants in Galicia during the last decades before WWI. ${ }^{2}$ However, they mostly ignored two important groups in

${ }^{1}$ Józef Chałasiński, Młode pokolenie chtopów. Procesy i zagadnienia kształtowania się warstwy chtopskiej $w$ Polsce, 4 vols. (Warsaw, 1938), republished in idem, Dzieta wybrane, i-iv, ed. Jan Szczepański (Warsaw, 1984).

${ }^{2}$ On peasants in Western Galicia see Jan Molenda, Chtopi - naród - niepodlegtość. Ksztaltowanie sie postaw narodowych i obywatelskich chtopów w Galicji i Królestwie 
Eastern Galicia, the 'Mazurians', as the Polish speaking and Roman Catholic peasants in Eastern Galicia usually were called, and the latynnyky, Ukrainian speaking peasants of Roman-Catholic religious denomination. Several hundred thousand villagers belonged to these groups. They have been largely ignored both in research on the period before WWI as well as in research on the interwar period. ${ }^{3}$ The following article does not aim at a comprehensive treatment of the developments among these groups, but offers, based on an analysis of different paths of political change in Western and Eastern Galicia before WWI, an explanation for differences in Chałasiński's findings on social and political attitudes among the generation of younger peasants in Eastern Galicia and in other parts of Poland. Chałasiński's collection of memoirs is one of the rare sources from the period before WWII where members of these groups within the rural population of Eastern Galicia present their own views.

II

PEASANTS VS. POLISH AND RUTHENIAN NATIONAL POLITICS IN AUSTRIAN GALICIA

On the eve of WWI rural society in Galicia was structured to a high degree according to national differences. Virtually all relevant political,

Polskim w przededniu odrodzenia Polski (Warsaw, 1999); Keely Stauter-Halsted, The Nation in the Village: The Genesis of Peasant National Identity in Austrian Poland, 1848-1914 (Ithaca, 2001); Michał Łuczewski, Odwieczny naród. Polak $i$ katolik $w$ Żmiącej (Monografie Fundacji na Rzecz Nauki Polskiej, Toruń, 2012); on Eastern Galicia John-Paul Himka, Galician Villagers and the Ukrainian National Movement in the Nineteenth Century (Houndmills, 1988); Andriy Zayarnyuk, Framing the Ukrainian Peasantry in Habsburg Galicia, 1846-1914 (Toronto, 2013). My own study attempts to compare attitudes towards and the integration of peasants into the Polish and Ruthenian movements, see Kai Struve, Bauern und Nation in Galizien. Über Zugehörigkeit und soziale Emanzipation im 19. Jahrhundert (Schriften des Simon-Dubnow-Instituts, 4, Göttingen, 2005).

${ }^{3}$ Some information on these groups can be found in Czesław Partacz, Od Badeniego do Potockiego. Stosunki polsko-ukrainskie $w$ Galicji w latach 1888-1908 (Toruń, 1996), 172-85; see also idem, 'Stosunki religijne w Galicji Wschodniej. Rusini-łacinnicy i Polacy-greko-katolicy', Rocznik Przemyski, xxviii (1991/1992), 123-47. For a discussion of the number of villagers belonging to these groups see below. A third group, that had some, though usually weaker connections to Polish identity, were peasants whose ancestors had belonged to the Polish gentry, the szlachta. On that group see fn. 54 . 
economic, and cultural organisations that were active in the villages had assigned themselves national tasks or saw their activities as a part of competing national projects, i.e. the strengthening of the Polish or Ruthenian nation. ${ }^{4}$ However, this did not mean that all villagers shared strong national identifications. For the large majority of the rural population religious affiliations and their social identity as peasants remained much more significant. ${ }^{5}$

Nevertheless, on the eve of WWI, there existed in nearly every village local branches of some countrywide national organisations. In many villages there were several of them. ${ }^{6}$ Among the Ruthenians of Eastern Galicia these were mostly reading rooms of the Prosvita or Kachkovs'kyı̆ Societies, cooperatives or branches of Sil's'kyı Hospodar, an organisation intended to improve the agricultural methods of peasants. In Western Galicia many Agrarian Circles of the Polish Association of Agrarian Circles (Towarzystwo Kótek Rolniczych, TKR)

${ }^{4}$ In the article the term 'Ruthenians' (Ukr. Rusyny; Polish Rusini; German Ruthenen) will be used for the period before WWI instead of 'Ukrainians'. This is based on the fact that until that period two major directions competed for support among the Ruthenians, i.e. the people belonging to the Greek-Catholic denomination, the rus'ka vira (Ruthenian belief), about how to understand their national identity as separate from the Polish one. Except for the Ukrainophile direction there was a strong Russophile one that considered the Ruthenians being a part of the Russian nation. Though already in a minority positions since the last decade of the 19th century, it was only after WWI and the Bolshevik revolution in Russia that the Russophiles became a marginal group in Eastern Galicia. Therefore, it seems to be inappropriate to use the term 'Ukrainian' that the Ukrainophiles had propagated as replacement of 'Ruthenian' already since the end of the 19th century in such a sense before the period after WWI. On the different national directions among the Ruthenians of Eastern Galicia see John-Paul Himka, 'The Construction of Nationality in Galician Rus': Icarian Flights in Almost All Directions', in Ronald Grigor Suny and Michael D. Kennedy (eds.), Intellectuals and the Articulation of the Nation (Ann Arbor, 1999), 109-64.

${ }^{5}$ The following section on Galicia before the WWI summarises results of my study Bauern und Nation.

${ }^{6}$ The inclusion of the villagers in modern, functional organisations that breached the isolation of the villages had reached a substantial level in the years before WWI. In their seminal study, The Polish Peasant in Europe and America, William I. Thomas and Florian Znaniecki described this as the way the national integration of the peasant population took place, see iidem, The Polish Peasant in Europe and America: Monograph of an Immigrant Group, 5 vols. (Boston, 1918-20), iv, pp. VIII-XII. 
had been established (and some also in Eastern Galicia). ${ }^{7}$ Several Polish organisations had been founded that should work for the improvement of the rural population's education. But except for the Society for Elementary Schools (Towarzystwo Szkoty Ludowej, TSL) during the last decade before WWI - I will discuss the specific features of this organisation below - all these organisations remained of a rather limited significance in rural areas of Eastern Galicia. This is especially striking when compared with the Ruthenian Prosvita and Kachkovs'kyĭ Societies. ${ }^{8}$

The main reason for this fact was mistrust and social distance between the Polish educated circles and the peasants that originated from the times of serfdom. Apparently, all social organisations as well as political parties of a countrywide significance that were active in rural areas could not develop and persist for longer periods without cooperation of both circles of the educated strata and peasants. The reason why since the 1870s and 1880s Ruthenian organisations spread more successfully than their Polish counterparts seems to have been that mistrust and fear both on the side of the intelligentsia and on the side of the peasants were smaller though they also existed. On the one hand, the Greek-Catholic peasants saw, based on a shared religious identity, attempts of the Ruthenian intelligentsia to establish reading rooms in the villages and to organise them politically to a higher degree as a positive, supportive endeavour that corresponded with their interests. On the other hand, the Ruthenian intelligentsia did not fear to the same degree as the Polish one independent political and social activism of the peasants. In fact, Ruthenian political parties could hope to win parliamentary seats only with active support of peasant voters against Polish competitors. Different forms of organisation reflected this difference in attitude. ${ }^{9}$

The Kachkovs'kyi Society was designed from its inception in 1874 as an organisation that should attract a large peasant membership with full membership rights. The Prosvita Society that had been founded already in 1868 changed its statutes in 1877 accordingly under the impression of the larger success of the Kachkovs'kyi

${ }^{7}$ On the Agrarian Circles also Antoni Gurnicz, Kótka rolnicze w Galicji. Studium spoteczno-ekonomiczne (Warsaw, 1967).

${ }^{8}$ Struve, Bauern und Nation, 125-90.

${ }^{9}$ For a comparison of Polish and Ruthenian political parties that tried to organise and represent the peasants, ibidem, 191-283. 
Society..$^{10}$ By contrast, nearly all Polish organisations that had been created with the purpose of educational and other work among the peasants were designed as organisations of the intelligentsia that worked among the peasants. They had no or nearly no peasant membership and, apparently, did not want to have it. Accordingly, peasants did not participate with membership rights in the decision-making processes within these organisations. ${ }^{11}$

While during the first election to the Galician diet in 1861 in the fourth, rural curia in Western Galicia mostly peasants were elected and in Eastern Galicia nearly all seats in that curia were won by Ruthenians, most of them peasants or Greek-Catholic priests, during the following years the Polish political elites worked hard to reduce the number of Ruthenians as well as peasants in the diet and in the parliament. Between 1876 and 1889 no peasant succeeded to win a seat in the diet in Western Galicia and also the number of Ruthenian deputies was strongly reduced. ${ }^{12}$

Only when in 1889 the Roman-Catholic priest and long-term editor of peasant papers Stanisław Stojałowski and a segment of the Galician democrats headed by Bolesław Wysłouch, Karol Lewakowski and Henryk Rewakowski broke with the Polish national solidarity in elections and supported the establishment of separate peasant electoral committees, four peasants or their candidates from Western Galicia reappeared in the Galician diet. This was the real beginning of the People's Party (Stronnictwo Ludowe) that is considered to have been

${ }^{10}$ On the Kachkovs'kyi Society Anna Veronika Wendland, Die Russophilen in Galizien. Ukrainische Konservative zwischen Österreich und Rußland 1848-1915 (Studien zur Geschichte der österreichisch-ungarischen Monarchie, 27, Vienna, 2001), 262-321; Paul R. Magocsi, 'The Kachkovs'kyi Society and the National Revival in Nineteenth Century East Galicia', Harvard Ukrainian Studies, xv, 1-2 (1991), 48-87. On Prosvita see Stepan Pers'kyı̆, Populyarna istoriya tovarystva "Prosvita" u L'vovi (L'viv, 1932), and Yaroslav Isaevych (ed.), "Prosvita". Oberig nezalezhnosti ta sobornosti Ukraïny (Ukraïna. Kul'turna spadshchyna, natsional'na svidomist', derzhavnist', 19, Lviv, 2010). On the foundation of both organisations Struve, Bauern und Nation, 142-8.

${ }^{11}$ See on these Polish initiatives Ryszard Terlecki, Oświata dorostych $i$ popularyzacja nauki $w$ Galicji $w$ okresie autonomii (Monografie z Dziejów Oświaty, 34, Wrocław, 1990), 25-76.

12 Jerzy Zdrada, 'Galicyjskie wybory sejmowe i parlamentarne w latach 18611889', Rocznik Biblioteki PAN w Krakowie, xix (1973), 229-56; Łuczewski, Odwieczny naród, 247-53; Struve, Bauern und Nation, 112-21. 
established formally only in 1895 . The election of 1889 signalled the beginning of increasing peasant political activism that rose slowly during the 1890s and accelerated further after the turn of the century. In rural Western Galicia it broke the political hegemony of the conservative landlords. In Eastern Galicia in the same period the Ruthenian political parties, especially those of the Ukrainian direction, rose in strength. ${ }^{13}$

While the Polish political elites in Galicia so far had feared any political activism of the peasants not only as a potential threat to their political dominance, but also to their property and even their lives, Wysłouch and his followers from the democratic intelligentsia drew practical consequences from an image of the Polish peasantry that the left wing of the Polish national movement had already nurtured for decades, i.e. that the peasantry, the lud, would become an active part of the national movement and take up the struggle for Polish independence. ${ }^{14}$ Wysłouch believed that this hope could only become real when the Polish national movement accepts peasants on an equal base within the national movement. Even more, he also believed that the peasants were the real 'core of the nation' (rdzen narodu) and every politics that claimed to be national politics had to put peasant interests in the first place. ${ }^{15}$ Such an understanding of Polish national

${ }^{13}$ Struve, Bauern und Nation, 191-236; Stauter-Halsted, Nation in the Village, 216-42; Łuczewski, Odwieczny naród, 253-96.

${ }^{14}$ On the changing image of the peasantry Peter Brock, Polish Revolutionary Populism: A Study in Agrarian Socialist Thought from the 1830s to the 1850s (Toronto, 1977); Franciszek Ziejka, Złota legenda chtopów polskich (Warsaw, 1984).

${ }^{15}$ That is the central argument of the Szkice programowe, an programmatic article, that the Lvov journal Przeglad Spoteczny, edited by Wysłouch, published in 1886. It is reprinted in Stanisław Lato and Witold Stankiewicz (eds.), Programy stronnictw ludowych. Zbiór dokumentów (Warsaw, 1969), 27-48. It is considered to be a founding document for the agrarian ruch ludowy. The quote is from the first programme of the Polskie Stronnictwo Ludowe that was adopted in 1903 and had been drafted by Wysłouch, ibidem, 69. On Wysłouch see Andrzej Kudłaszyk, Myśl spoteczno-polityczna Bolestawa Wystoucha 1855-1937 (Warsaw, 1978), and Peter Brock, 'Bolesław Wysłouch, Pioneer of Polish Populism', in idem, Nationalism and Populism in Partitioned Poland: Selected Essays (London, 1973), 181-211. On the Przeglad Spoteczny see Krzysztof Dunin-Wąsowicz (ed.), Przegląd Spoteczny 1886-1887 (Materiały do Dziejów Postępowej Publicystyki, 4, Wrocław, 1955), and Kai Struve, 'Galizische Verflechtungen - die "Judenfrage" in der Lemberger Zeitschrift "Przegląd Spoleczny" (1886-1887)', in Manfred Hettling et al. (eds.), Die "Judenfrage" - ein europäisches Phänomen? (Studien zum Antisemitismus in Europa, 5, Berlin, 2013), 95-126. 
identity provided the base for a cooperation of peasants and members of the intelligentsia in this new political movement. This movement developed a concept of Polish national identity that allowed expressing peasant social and political interests. Thereby, it also became attractive for politically active peasants. By reference to the peasants' significance for the nation they could demand to take account of their social and political interests. ${ }^{16}$

However, the Polish peasant political activism associated primarily with the Stronnictwo Ludowe remained mostly restricted to Western Galicia. No similar political movement developed among the 'Mazurian' peasants in Eastern Galicia. Polish politics in the rural areas of Eastern Galicia remained dominated by the conservatives and increasingly by the National Democrats. ${ }^{17}$ Here the Ruthenian parties represented peasant interests. In Eastern Galicia, the work of the Polish intelligentsia among the peasantry continued in the traditional form of a patronising work for and among the peasants.

In Eastern Galicia, since the last years of the nineteenth century Polish work among the peasants became increasingly dominated by the TSL. This organisation had been founded in 1892 by the Galician democrats. Already from the beginning there had been a strong National Democratic current within the organisation that since 1902 had the majority of its board. In the following decade the organisation was able to extent its activities substantially. By contrast to earlier educational societies, it saw its work clearly as part of a national struggle against the Ruthenians in the East and the Germans in the West, where it concentrated its activities on Silesia. It established Polish schools, but developed also a wide range of other educational activities. For example, it increased the number of its reading rooms from 82 in 1901 to 1529 in 1913. This increase reflected also the rise in the number of Polish youth with higher education and their increasing civic and national activism. They mostly carried the work of this organisation. ${ }^{18}$

${ }^{16}$ Molenda, Chtopi - naród - niepodlegtość, 172-289; Struve, Bauern und Nation, 323-61.

${ }^{17}$ Adam Wątor, Ziemianin-polityk Tadeusz Cieński 1856-1925. Z dziejów konserwatyzmu wschodniogalicyjskiego (Rozprawy i Studia - Uniwersytet Szczeciński, 258 [332], Szczecin, 1997); idem, Narodowa demokracja w Galicji do 1918 roku (Rozprawy i Studia - Uniwersytet Szczeciński, 428 [502], Szczecin, 2002).

${ }^{18}$ On the TSL see Struve, Bauern und Nation, 164-70; Maria Jolanta Żmichrowska, Towarzystwo Szkoly Ludowej (1891-1939) (Olsztyn, 1992); Anna Zwiercan- 
One of the largest and most active circles of the TSL existed in Tarnopol (Ukr. Ternopil'), a region with a strong 'Mazurian' share among the rural population. The Tarnopol circle was one of the strongholds of the National Democrats within the TSL. The National Democrats had a similar origin as the peasant movement in Galicia, i.e. as part of a new current among the Polish intellectuals in the 1880s that wanted a stronger focus on the interests of the plebeian classes, primarily the peasantry, in Polish national politics. While the Galician Stronnictwo Ludowe actually organised an active involvement of peasants in politics, the National Democrats soon developed a hierarchical concept that imagined the nation primarily as a disciplined army in the permanent struggle with other nations. ${ }^{19}$ In its annual report for 1903 the TSL's Tarnopol branch complained that the lud only slowly "awakes from its century-long dullness and passivity". ${ }^{20}$ Ten years later it reported already more initiative from among the peasantry, but maintained a strong claim for leadership by the intelligentsia that also revealed a radical nationalistic, in a way proto-fascist image of the nation:

The formless and cold bloc that our Polish lud in Podolia so far has been warmed up and changed during the last decade in a characteristic way. It is to be desired that there will be no lack of able masters and strong hammers that will forge as soon as possible a beautiful and living figure of the reborn Slavic Lechita. ${ }^{21}$

Such a view of the peasantry was far away from that of the Stronnictwo Ludowe that saw the peasantry itself in a role of leader and administrator of political power. Apparently, in Eastern Galicia the work of the Polish intelligentsia among the peasants did not lead to an active, sustainable involvement of peasants into national politics.

-Witkowska, ‘Towarzystwo Szkoły Ludowej w latach 1891-1939', Biuletyn Biblioteki Jagiellońskiej, liii (2003), 135-55.

${ }^{19}$ On the development of the National Democrats and their political ideas see Brian Porter, When Nationalism Began to Hate: Imagining Modern Politics in NineteenthCentury Poland (Oxford, 2000). More extensively on activities among and attitude towards the peasants Tadeusz Wolsza, Narodowa Demokracja wobec chtopów w latach 1887-1914. Programy, polityka, działalność (Warsaw, 1992).

${ }^{20}$ Sprawozdanie Zarzadu Kota Towarzystwa 'Szkoty Ludowej' w Tarnopolu za rok 1903 (Tarnopol, 1904), 10.

${ }^{21}$ Sprawozdanie Zarzadu Koła Towarzystwa 'Szkoty Ludowej' w Tarnopolu za rok 1913 (Tarnopol, 1914), 22. 
III

\section{POLISH PEASANTS IN EASTERN GALICIA}

IN THE INTERWAR PERIOD

The years of WWI and the following Polish-Ukrainian conflict of 1918-9 brought much destruction, sufferings, and an exacerbation both of the national conflict and the social tensions into Eastern Galicia. ${ }^{22}$ Ukrainian hopes for a nation state collapsed, but remained on the political agenda. During the first years of the Polish state some former members of the Ukrainian military continued the struggle by terrorist attacks in Eastern Galicia. In 1929, the Ukrainian underground organisation, the Ukraïns'ka viı̌s'kova organizatsiya (UVO), transformed into the Organizatsiya ukraïns'kykh natsionalistiv (OUN), that during the 1930s attracted broader segments of the Ukrainian youth in rural areas and took up again the terrorist struggle against the Polish rule in Eastern Galicia and Volhynia. The denial of the implementation of autonomy for Eastern Galicia that the Polish state had promised in order to get international recognition of its eastern borders in 1923, remained a constant bone of contention in mutual relations. The initial boycott of Polish state institutions, including elections to the Polish parliament in 1922, by the Ukrainian political parties in Eastern Galicia was only slowly overcome. Attempts of more moderate forces on both sides to find some form of agreement had only short-term effects. In general, also the nationalistic tensions in the countryside rose, compared to Austrian times, considerably. Violent attacks by Ukrainian nationalists on Polish officials, Polish institutions or property and also on moderate Ukrainians became a constant feature of the political situation in Eastern Galicia. ${ }^{23}$

22 Torsten Wehrhahn, Die Westukrainische Volksrepublik. Zu den polnisch-ukrainischen Beziehungen und dem Problem der ukrainischen Staatlichkeit in den Jahren 1918 bis 1923 (Berlin, 2004); Michał Klimecki, Polsko-ukrainska wojna o Lwów i Galicje Wschodnia 1918-1919 (O Wolność i Niepodległość, Warsaw, 2000); Mykola R. Lytvyn and Kim Ye. Naumenko, Istoriya ZUNR (Lviv, 1995).

${ }^{23}$ Ryszard Torzecki, Kwestia ukraińska w Polsce $w$ latach 1923-1929 (Cracow, 1989); Alexander J. Motyl, The Turn to the Right: The Ideological Origins and Development of Ukrainian Nationalism, 1919-1929 (East European Monographs, 65, Boulder, 1980); Roman Wysocki, Organizacja Ukrainskich Nacjonalistów w Polsce w latach 1929-1939. Geneza, struktura, program, ideologia (Lublin, 2003); Robert Potocki, Polityka państwa polskiego wobec zagadnienia ukrainskiego w latach 1930-1939 (Lublin, 2003). 
How, under these circumstances, did develop Polish national identifications among the rural population? It has been argued above that before WWI on the one hand the national structurisation of society had been far advanced, but that on the other hand national identifications for many among the rural population did not have great significance. It has been also argued that with the development of the Polish peasant movement, the ruch ludowy, a specific understanding of Polish national identity spread among politically active peasants that emphasised the national quality and significance of the peasantry in order to support their political and social claims. Such an understanding of Polish national identity supported the national identification of peasants. Therefore, in areas where the peasant movement was strong, Polish national identity was significant for more peasants than in regions where the peasant movement had no or only small influence. This would suggest that peasants in Western Galicia felt more strongly as Poles than the Eastern Galician 'Mazurians'. However, one might also assume that here the strong movement among the Ruthenians had an effect on the non-Ruthenian peasants. They either may have felt the need to organise themselves against a Ruthenian dominance or may have joined the Ruthenians and increasingly abandoned cultural traits as language or religion that connected them to Polish national identity.

The Polish population in Eastern Galicia - in independent Poland, that region consisted of the voivodeships of Tarnopol, Stanisławów (today Ivano-Frankivsk) and the eastern part of the Lvov voivodeship - constituted a strong segment of the population of cities and towns, but in certain regions it had also a large share among the rural population. According to the Polish population census of 1931 about 1.86 million of the 4.73 million inhabitants of Eastern Galicia, i.e. 39.3 per cent, declared Polish as their language compared to 52.75 per cent who declared Ukrainian or 'Ruthenian'. Results concerning religious belongings that often were identified with Polish or Ukrainian national identity were somewhat different. 28.6 per cent declared to be members of the Roman-Catholic church while about 60 per cent declared to belong to the Greek-Catholic Church. ${ }^{24}$

The census and its results were part of the Polish-Ukrainian conflict about Eastern Galicia. When the results were announced the

${ }^{24}$ Grzegorz Hryciuk, Przemiany narodowościowe $i$ ludnościowe w Galicji Wschodniej $i$ na Wotyniu w latach 1931-1948 (Toruń, 2005), 75 f. 
Ukrainian public criticised them as being falsified and presenting the share of the Ukrainians as too low. In contrast to the census of 1921, when the Ukrainian parties had called for a boycott, in 1931 they urged the Ukrainians to participate in order to prove the strong Ukrainian presence in the region. Grzegorz Hryciuk's recent study confirms, based on a thorough analysis of the census and other data, that the Ukrainian critique of the results to a certain degree was true. The census exaggerated not only the share of those who declared Polish language, but also the share of the Roman-Catholic population - according to Hryciuk of about 4 per cent on the cost of the Greek-Catholic group..$^{25}$

Nevertheless, while containing a certain distortion of numbers that has to be born in mind, the census provides some important information. It is well known that Poles and Jews were the most important groups of the inhabitants in most of Eastern Galicia's cities and towns. Despite this fact, city dwellers constituted, according to the census, only 17.5 per cent of the Polish population in Tarnopol voievodeship and 35 per cent in the voievodeship of Stanisławów. Nearly 69 per cent of the Polish population of the voievodeships of Tarnopol, Stanisławów and Lvov (including its western part) earned their living from agriculture. ${ }^{26}$ The numbers, even if they are too high, clearly show that in Eastern Galicia there was a peasant population of several hundred thousand who had connections to Polish identity by religion or language. However, as the following analysis will show, Polish national identification among them was rather weak.

In the following part of the paper I would like to analyse how Polish national identifications developed among peasants of Eastern Galicia during the interwar period. This analysis will be mostly based on autobiographies of young peasants that the sociologist Józef Chałasiński collected in 1937 and analysed in his monumental work Mtode pokolenie chtopów where he also published many autobiographies in full or in longer excerpts. Two years before there had been published already another important collection of peasant autobiographies from the interwar period, i.e. the two volume Pamiętniki chtopów. It originated from a call for writings issued in 1933 by the Instytut Gospodarstwa Spotecznego headed by the Marxist sociologist Ludwik

25 Ibidem, 115.

${ }^{26}$ Ibidem, 81. 
Krzywicki, who also wrote an introductory analysis. ${ }^{27}$ However, this collection included only one autobiography from Eastern Galicia and Krzywicki's introductory survey of the autobiographies addressed the problem of the peasants' national attitudes only in passing. He did not refer to the situation in specific regions. ${ }^{28}$ While Chałasiński aimed at a sociological analysis of changes in attitudes, ambitions, values, and experiences of the peasant strata, the collection of Krzywicki's institute intended primarily to expose the peasants' poverty and misery that had increased as a result of the economic crisis since the end of the 1920s. ${ }^{29}$ The only autobiography from Eastern Galicia in Krzywicki's collection, that had been written by a peasant from the district of Buczacz did not address relations with Ukrainians. Like the others in this collection, it stressed the economic misery and briefly referred to a disappointment of the peasants with the Polish state because of the peasants' economic decline and poverty. ${ }^{30}$

In 1937, Chałasiński had published a call for autobiographical descriptions of "life, work, deliberations and aspirations" of rural youth below the age of thirty in the paper 'Przysposobienie rolnicze' and subsequently in several papers on organisations of rural youth. ${ }^{31}$ The response was unexpectedly strong. He received 1544 autobiographical writings from the whole of Poland and members of all different rural youth organisations. The length of the writings ranged from several to several dozen pages. The authors of the best texts were awarded scholarships for agricultural education or prizes in books or money. ${ }^{32}$

Chałasiński, a former student of Florian Znaniecki, here used a method that the Polish sociology had developed since the 1920s. This method was based on the theoretical assumption that social

${ }^{27}$ Pamiętniki chtopów, 2 vols. (Warsaw, 1935-6).

${ }^{28}$ Ludwik Krzywicki, 'Nieco o pamiętnikach i pamiętnikarzach', ibidem, i, pp. XIX-XLII.

${ }^{29}$ The call for writings that the Instytut Gospodarstwa Wiejskiego issued, strongly suggested to expose the economic hardship that many peasants suffered from. Consequently, many writings focused on poverty and economic decline. For a critique of this bias see Władysław Grabski, 'Pamiętniki chłopów i środowisko społeczne wsi polskiej', Przeglad Socjologiczny, iv, 3-4 (1936), 297-340.

${ }^{30}$ Pamiętniki chtopów, i, 701-14, here: 705, see also 701.

${ }^{31}$ The call is reprinted in Chałasiński, Młode pokolenie chtopów, i, pp. XXIV-VI.

32 Ibidem, XXVI f., XXXV-VII, 1. On Chałasiński's collection see also Włodzimierz Mędrzecki, Młodzież wiejska na ziemiach Polski Centralnej 1864-1939. Procesy socjalizacji (Warsaw, 2002), 13-21. 
reality is the result of individual attitudes, values, and aspirations that create the structures of society. This theory had been developed by William Thomas and Florian Znaniecki in their seminal work The Polish Peasant in Europe and America, published in five volumes in 1918-20. ${ }^{33}$

In his analysis of the autobiographies of peasant youth Chałasiński came to the conclusion that they identified with Poland in a much stronger way than the generation of their parents because, practically, they knew only life in a Polish state. ${ }^{34}$ In general, Chałasiński in a sharp contrast to Krzywicki's description drew a very positive, optimistic picture of the younger generation of peasants. He stressed their social activism that expressed itself in activities in many different organisations in the villages, in better education and in a strive for improvements in agriculture. ${ }^{35}$ However, Chałasiński, himself a son of a scribe from a village near Lublin, is not free of a certain pathos of peasant patriotism that was characteristic for the peasant movement. This is evident when he, for example, writes that the peasantry had become "aware of its rights and strength and with the rising feeling of its power it consciously takes over the responsibility for the future fate of Poland." 36 At another place he praised the peasants' participation in military units during the struggle for independence during and after WWI. ${ }^{37}$

Chałasiński is strongly critical of the educated strata of Polish society and their attitude towards the peasantry. He finds that arrogance and paternalism towards peasants continued into the Second Republic. The Polish intelligentsia did not accept peasants as equal. ${ }^{38}$ When Chałasiński writes about two different, at least partially contradictory cultures, existing in Polish society, 'a culture of the intelligentsia' and 'a peasant culture', he suggests that in this respect not much had changed since the 1880s when Jan Ludwik Popławski

33 Thomas, Znaniecki, The Polish Peasant. Thomas and Znaniecki did not use materials that were created for the purpose of research, as Chałasiński did, but other individual materials as letters or diaries.

${ }^{34}$ Chałasiński, Młode pokolenie chtopów, i, 2.

${ }^{35}$ Ibidem, 8.

${ }^{36}$ Ibidem, 13. When he also states that peasant children who acquire higher education usually lose positive moral features of the peasant strata, he seems even to take up some of the more problematic ideas of interwar agrarianism, ibidem, $46 \mathrm{f}$. Critical about the "intelligentsia of peasant descent" also pp. 95-9.

${ }^{37}$ Ibidem, $66 \mathrm{f}$.

${ }^{38}$ Ibidem, 13-47. 
published his famous article about the 'two civilisations' within the Polish nation. ${ }^{39}$ More clearly, Chałasiński states in another part of his work that until his days "the basic structure of Polish society is that it consists of two strata: peasants and lords (chtopi i panowie)." 40 He considered being 'peasant' or 'lord' the two 'social-customary models' in social perception and, thereby, social reality of the Second Republic. ${ }^{41}$ In this perception the peasant existed, as Chałasiński put it bluntly, only for work while the pan (lord) was considered to be an 'autonomous being' that did not need any further justification in order to give his existence and actions a sense. ${ }^{42}$ Among the perceptions of both groups Chałasiński counted also that the lords existed to rule and the peasants to work ("chłopa do roboty i pana do rządzenia"). ${ }^{43}$ He accused the rule of Piłsudski's followers and their disregard of peasants and their interests as a new szlachetczyzna - the (bad) rule of the Polish gentry, that deepened the abyss between the two groups in Polish society. ${ }^{44}$

Furthermore, Chałasiński shows clearly how views and values that the Polish peasant movement had developed before WWI continued to spread among the peasant youth in the interwar period. In a certain contrast with Krzywicki's findings Chałasiński did not conclude that the rising social and political tensions in Polish society during the 1930s resulted into an alienation of the peasant youth from Polish national identity and the Polish state. In his view, social radicalism was combined with increasing peasant self-confidence. The young peasants did not reject the nation, but claimed its leadership. ${ }^{45}$

In the second volume of his work where Chałasinski gives an analysis of the peasant youth's autobiographies in the different

${ }^{39}$ Ibidem, 46. Popławski's article, published in the first issue of the Warsaw journal Gtos in 1886, criticised the social distance between the educated classes in Polish society and the "people" and called both for the latter's equal treatment and a recognition of their social interests as a precondition to gain their support for Polish national aims. On this article in the context of the Polish political debates of the 1880s see Porter, When Nationalism Began to Hate, 112-7.

${ }^{40}$ Chałasiński, Młode pokolenie chtopów, i, 69.

${ }^{41}$ Ibidem, 72.

42 Ibidem; see also 83-95.

${ }^{43} \mathrm{Ibidem}, 99$.

${ }^{44}$ Ibidem, 101-10.

${ }^{45}$ Ibidem, 118 f., 163 f.; Ludwik Krzywicki, 'Kiedyś zadnieje?', in Pamiętniki chtopów, i, pp. V-XVI, here: X f. 
regions of the Polish state, for Eastern Galicia he presents a much less optimistic account of changes in the Polish peasantry as he did for other regions and in the general parts of his study. He characterised the writings that he received from this region as "extremely poor and weak". The number was small and apparently also the quality of descriptions and reflections was humble. ${ }^{46}$ The writings also suggested a low level of organisation among the peasant youth in who region. The percentage of peasant youth among the writers who did not belong to any organisation here was higher than in all other regions. ${ }^{47}$

Nevertheless, during the first years of the Second Republic the Polish People's Party (Polskie Stronnictwo Ludowe, PSL) 'Piast' that dominated in rural Western Galicia gained also a certain influence in Eastern Galicia. As a result of the Ukrainian parties' boycott of the elections to the Sejm in 1922 the PSL 'Piast' could win here twenty seats and became the strongest party in Eastern Galicia in front of the (National Democratic) Christian Union of National Unity (Chrześcijański Związek Jedności Narodowej) that got fourteen seats. In Eastern Galicia the PSL 'Piast' had its best result in the election district 54 that comprised the southern parts of the Tarnopol Voievodeship, an area with a large share of Roman-Catholic or Polishspeaking rural population. Here it got 43.6 per cent of the votes. But because of the Ukrainian boycott only 34.6 per cent of the voters had cast their ballots. ${ }^{48}$

In spring 1921, the party's newspaper Piast claimed that there existed several hundred of its party circles in Eastern Galicia. ${ }^{49}$ In autumn 1925, the party's leadership stated that in the villages of the Tarnopol voivodeship "except for the ludowcy there is no one", i.e. there is no other Polish party than the PSL. ${ }^{50}$ However, by contrast to the areas of Western Galicia where this party had a strong influence

${ }^{46}$ Chałasiński, Młode pokolenie chłopów, ii, 132.

${ }^{47}$ Ibidem, 137 f.; see also p. 2. On organisations of rural youth in interwar Poland see Alicja Więzikowa, 'Od rozbicia do zjednoczenia (1926-1931)', in Jan Borkowski et al. (eds.), Zarys historii ruchu ludowego, ii: 1918-1939 (Warsaw, 1970), 187-331, here: 252-65.

${ }^{48}$ Mirosława Papierzyńska-Turek, Sprawa ukraińska w Drugiej Rzeczypospolitej 1922-1926 (Cracow, 1979), 137-40.

${ }^{49}$ Piast, no. 13, March 27, 1921, p. 9. Here the paper reported also about a large rally in Lvov with more than 5,000 participants.

${ }^{50}$ Jan Borkowski, Ludowcy w II Rzeczypospolitej, 2 vols. (Warsaw, 1987), i, 275. 
no details are known about its party organisation in Eastern Galicia, probably indicating that the organisational structures were rather weak compared to other areas. ${ }^{51}$ This is confirmed by the fact that the Polish peasant parties lost most of their support in Eastern Galicia in favour of pro-Sanacja parties in the following elections in $1928 .^{52}$

Nearly all authors from Eastern Galicia who responded to Chałasiński's call for autobiographies describe a strong antagonism with the Ukrainians and are impressed by the strength of the Ukrainian organisations as compared to the Polish ones. ${ }^{53}$ Chałasiński reports that unlike to those from Eastern Galicia many writings from Volhynia, where the Ukrainian nationalist movement was weaker, described attempts of joint initiatives between Ukrainian and Polish peasants. From Eastern Galicia, Chałasiński received only one autobiography written in Ukrainian. It had been sent in by the son of a poor Ukrainian peasant who had to leave an Ukrainian organisation because he could not pay the fees. Two autobiographies came from the Hutsul region. One of the authors was a supporter of a Hutsul nation and, apparently, was in close contact with Polish nationalists who attempted to weaken Ukrainian influence by supporting regional identities. ${ }^{54}$ The other sent a long, well-written account, but avoided, probably consciously, all directly political subjects or those related with the national conflict. He focused nearly solely on personal or agricultural matters and his agricultural education. ${ }^{55}$

It is characteristic that several autobiographies that Chałasinski cites were written by sons and daughters of Polish settlers in Eastern

${ }^{51}$ Ibidem. When a major split in the parliamentary faction of the PSL 'Piast' occurred in 1925, most of its members from Eastern Galicia joined the newly founded Stronnictwo Chtopskie. These conflicts may have contributed to the weakening of the organisational structures in the region.

${ }^{52}$ Tomasz Szczechura, 'Wyniki głosowania w obwodach wiejskich na listy polskie podczas wyborów do Sejmu w latach 1919, 1922 i 1928', Roczniki Dziejów Ruchu Ludowego, x (1968), 66-121, here: 109-11, 114.

${ }^{53}$ Chałasiński, Młode pokolenie chtopów, ii, $132 \mathrm{f}$.

${ }^{54}$ Another means for this aim were attempts of the Polish government to revive traditions of former membership in the Polish gentry, the szlachta, among some groups of both Greek-Catholic and Roman-Catholic peasants in Eastern Galicia that began for the most part in the middle of the 1930s, see Potocki, Polityka państwa polskiego, 174-85.

${ }^{55}$ Chałasiński, Mtode pokolenie chtopów, ii, $132 \mathrm{f}$. That account is reprinted in full length ibidem, iii, 305-32. 
Galicia. Apparently, their civic activism and Polish nationalism was much stronger than that of the indigenous Roman-Catholic and Polish speaking population. In the beginning of the 1920s many Poles, mostly peasants from Western Galicia, acquired land in Eastern Galicia that after the devastations of the war in that region was relatively cheap. This was not a part of the settlement of Polish veterans - 'the military settlement', that exacerbated relations between the Polish state and the local population in Volhynia and the northeastern borderlands -, but a mostly privately organised movement for economic reasons that, nevertheless, had a certain support from the administration and Polish political parties. When the legal basis and the institutions for implementing the land reform had been created in the beginning of the 1920s, they organised or regulated the settlement. ${ }^{56}$ Like the military settlement, also these settlers experienced a hostile relationship with their Ukrainian neighbours because for them the settlers were competitors for land of which the Ukrainian peasants believed that they had a right to. ${ }^{57}$

In view of a rising population and a lack of land in Western Galicia, the Stronnictwo Ludowe already before the war had supported the settlement of Polish peasants in Eastern Galicia. After the war the PSL 'Piast' propagated such a settlement similar to the military

${ }^{56}$ Between 1919 and 1934, 11,192 of 14,817 farms subdivided from large estates in the voievodeships of Lvov, Tarnopol and Stanisławów were acquired by Polish settlers. It is estimated that between 44,000 and 55,000 Poles moved into Eastern Galicia as result of this settlement, see Vasyl' Smoleř, 'Pol's'ke sil's'kogospodars'ke osadnytstvo v Zakhidniǐ Ukraïni 1920-1939 rokiv', Ukrä̈na v mynulomu, ix (1996), 163-76, here: 168-71; Hryciuk, Przemiany narodowościowe, 86. Jan Bryl, a member of the Sejm for the PSL 'Piast' from Eastern Galicia, mentioned in February 1922 even 100,000 Poles who had moved to that region, Piast, no. 8, Feb. 19, 1922. Higher numbers are quoted also by Stephen M. Horak, 'Belorussian and Ukrainian Peasants in Poland, 1919-1939: A Case Study in Peasantry under Foreign Rule', in Ivan Volgyes (ed.), The Peasantry of Eastern Europe, i: Roots of Rural Transformation (Comparative rural transformation series) (Pergamon policy studies, 5, New York, 1979), 133-56, here: 138. On the military settlement in Volhynia and the northeastern voivodeships see Janina Stobniak-Smogorzewska, Kresowe osadnictwo wojskowe 1920-1945 (Seria Wschodnia, Warsaw, 2003).

${ }^{57}$ When in September 1939 Polish state authorities dissolved, except for members of the Polish Police, Armed Forces and other officials, it was the settlers who were attacked by Ukrainian nationalist groups, but not the 'Mazurians', Andriĭ O. Rukkas, 'Zbroĭni zagony Organizatsiï ukraïns'kykh Natsionalistiv na Berezhanshchyni (veresen' 1939 r.)', in: Ukrä̈ns'kyi vyzvol'nyı̃ rukh, 3 (2004), 145-59. 
settlement with nationalistic arguments that also had a resonance among the settlers. Already Bolesław Wysłouch's 'Programmatic Sketches' (Szkice programowe) of 1886, a foundational document of the peasant movement, had expressed the conviction that only those territories were in the secure possession of the Polish nation where Polish peasants settled. However, the Szkice programowe had resigned from the territories east of the river San for the Polish nation because they had a majority of Ukrainian inhabitants. ${ }^{58}$ Later, the PSL and PSL 'Piast' kept only to the first of these two programmatic statements. ${ }^{59}$

Conditions for the settlers often were difficult. Referring to their role in the defense of the Polish national interests against hostile Ukrainians, the settlers demanded support from the Polish state. ${ }^{60}$ Chałasiński included into his study a lengthy quote from the account of a settler's daughter who had moved to Eastern Galicia in 1921 from Mielec district in Western Galicia. Her parents had sold their house with half an acre and a cow for 120,000 Polish marks and acquired seven acres - four acres cropland and three acres forest -

${ }^{58}$ Lato and Stankiewicz (eds.), Programy stronnictw ludowych, 39.

59 So, e.g., in a joint declaration the PSL 'Piast's' deputies to the Viennese Reichsrat and the Galician Sejm from January 1918, demanded not only a land reform, i.e. the distribution of estate land between smallholders, but they declared also "in view of the fact that Poland's borders go as far as the Polish land is in possession of the Polish peasant ... and that land is the basis of the nation's existence, the club of the PSL deputies determines as its dogma that for land that anywhere is in Polish possession and should go into other hands Polish peasants should have precedence"; Materiaty źródłowe do historii polskiego ruchu ludowego, 4 vols. (Warsaw, 1966-7), i: 1864-1918, ed. Krzysztof Dunin-Wąsowicz, 451 f. See also Wincenty Witos, Moje wspomnienia, i, 1, ed. Eugeniusz Karczewski and Józef Ryszard Szaflik (Dzieła wybrane, 1, Warsaw, 1988), 30 f. When in May 1920 Wincenty Witos pushed increasingly strongly for a law on land reform he also put forward the argument that in Eastern Galicia land of Polish estates was acquired by Ukrainian peasants without any control while Polish peasants suffered from a lack of land. He wanted a state controlled subdivision of estates that privileged Polish peasants, Piast, no. 21, May 23, 1920, 4; see also Andrzej Chojnowski, Koncepcje polityki narodowościowej rządów polskich w latach 1921-1939 (Polska Myśl Polityczna XIX i XX wieku, 3, Wrocław, 1979), 46.

${ }^{60}$ This demand was adopted by the PSL 'Piast'. On Feb. 5, 1922 the PSL 'Piast' organised a meeting of settlers from Eastern Galicia in Lvov where their needs were discussed, Piast, no. 7, Feb. 12, 1922, 7. See also the speech of the PSL 'Piast' deputy Jan Bryl that he presented in the Sejm on Feb. 10, 1922, Piast, no. 8, Feb. 19, 1922, 4-7. 
near Stanisławów for 150,000 Polish marks. The land had laid waste as a result of the war. The author belonged to the radical peasant youth organisation Rural Youth Union (Związek Młodzieży Wiejskiej) 'Wici'. She phrased the motivation of her father to move to the east in very patriotic terms. They showed that she expected an economic reward as compensation for her father's active participation in the wars for Polish independence. At the same time the author struggles with a contradiction that characterised also the attitude of the Polish peasant parties towards the Slavic minorities. On the one hand there was the wish to acquire land in the East for Polish peasants and on the other hand the belief in shared social interests with the mostly peasant Ukrainians and Belarusians. The competition over land alienated the latter from the Poles while the peasant parties otherwise believed that respect for peasant social interests could also attract Ukrainians and Belarusians to the Polish state. ${ }^{61}$ After having mentioned her father's dreams of an independent Poland while serving during WWI she referred to a statement of the peasant party politician Jan Dąbski who had negotiated the new Polish border in the east with the Soviets at the peace talks in Riga in 1921:

When in resurrected Poland the slogans of social reforms were proclaimed and Jan Dąbski said that in the East Poland rests on the white little peasant huts and not on the nobility's palaces, I then thought that the blood had not been spilled as well as the hunger and the war's adversities had not been suffered in vain. But then these huts in the East, on which Poland should rest, became disregarded and the system forgot them and the white huts in the East and the land, that had been spilled with plenty of Polish blood, went for next to nothing into the hands of Poland's enemies, the Ukrainians, because though they are our brothers they are, nevertheless, secret enemies of Poland who want to remove as many settlers as possible from Eastern Lesser Poland, and the governing elements do not care to prevent that and do not care for strengthening the Polish element in the borderlands. ${ }^{62}$

${ }^{61}$ Such an attitude especially characterised the Galician PSL 'Piast'; Kai Struve, “"Chłopi z chłopami” albo "Ziemia polska dla Polaków”. Das Verhältnis des ruch ludowy zu Weißrussen und Ukrainern bis 1939', in Grzegorz Kotlarski and Marek Figura (eds.), Oblicza Wschodu w kulturze polskiej (Poznańskie Studia Wschodoznawcze, Poznań, 1999), 99-122.

${ }^{62}$ Chałasiński, Młode pokolenie chtopów, ii, 144 (autobiography no. 1277/155, Wici). 
Many of the settlers who had come to Eastern Galicia in the beginning of the 1920s left the region again in the following years. The authors of the autobiographies mention the hostile attitude of the Ukrainians as the main reason. But economic difficulties in establishing new farms certainly also played a major role. ${ }^{63}$ So, for example, the son of a settler from a settlement near Stanisławów reported that from his community

already several sold and returned to the west and they sold into the hands of the Ukrainians. It should not happen that Polish fields go into the hands of the Ruthenians because we came here in order to Polonise. Who is guilty of that, I don't know, but it seems that the government is guilty. ${ }^{64}$

Ten of the originally 62 settlers in this settlement had sold their property to Ukrainians. The daughter of a settler who had moved from near Cracow to a village near Kolomija reported a somewhat different story about rising national antagonisms in the village. She had finished a teachers seminary in Kolomija and organised a female branch of the Riflemen's Association (Zwiazek Strzelecki) in her village where 90 per cent of the inhabitants were Ukrainians, "in order to protect them [the girls/the women] from Ruthenisation." She attested to the other Poles who were not settlers a high degree of assimilation to the Ukrainians and a cautious attitude of the women to her organisational endeavor:

Only reluctantly they agreed to become members because they had no social sense and they did know only little about the fact that they are Polish. They were staying in the company of Ruthenian boys and talked to them in Ruthenian. Some even dressed in the Ruthenian way. They had embroidered shirts and skirts wide like umbrellas. They went to the Greek-Catholic church, but were not guilty of that because there was

${ }^{63}$ In July 1922 Piast wrote about a 'flight psychosis' among the settlers in Eastern Galicia, 'Zaprzepaszczenie osadnictwa na kresach wschodnich', Piast, no. 27, July 2, 1922, 5 f. The ethnologist Józef Gajek who did some field research in villages in the Tarnopol region in the 1930s concluded that the "so-called 'Witos'-colonisation failed nearly completely. About 85 percent of the wave of colonists has flown off again. Nevertheless, it created much discontent among the Polish and the Ruthenian population"; Józef Gajek, Problemy etniczne i narodowościowe na Podolu. Odczyt zorganizowany $w$ Tarnopolu staraniem Podolskiego Towarzystwa Przyjaciót Nauk (Tarnopol, 1937), 50; see also Hryciuk, Przemiany narodowościowe, 86.

${ }^{64}$ Chałasiński, Mtode pokolenie chłopów, ii, 136 (autobiography no. 663/88, Z.S.). 
no Roman-Catholic church in T. Some Poles could not stand the repulsive atmosphere of that village and sold everything and moved into a Polish village. Of course, Ruthenians bought the land ... . ${ }^{65}$

Also other Polish villagers from Eastern Galicia reported a continuation of assimilation of Roman-Catholic, Polish speaking peasants toward the Ukrainian majority. The son of a smallholder from Rudki district wrote that about 10 per cent of the 400 inhabitants of his village were Poles, but did not speak Polish. Only when he had organised a circle of Zwiazek Młodzieży Wiejskiej they started to speak Polish. He had given lectures and taught them to sing Polish folk songs (!). For this work he had received death threats from Ukrainians. A leader of the Ukrainians had also threatened and violently attacked a Ukrainian women and a Pole who attended a barn dance organised by the Poles. ${ }^{66}$

Chałasiński concluded that the peasant character of the Ukrainian nationality attracted the Polish peasants to them:

The peasant character (chtopskość) of [Ukrainian] society is one of the most powerful sources of the attractiveness of Ukrainian society in relation to the Polish peasant. In everyday life the Ukrainian peasant is closer to the Polish peasant than the Polish professional (inteligent) .... .

Chałasiński who argued here very much within a Polish national discourse, i.e. he apparently regretted the lack of assimilatory power of the Poles in relation to Ukrainians in rural areas, regarded as its reason the weakness of Polish organised society in Eastern Galicia.

65 Ibidem, 134 (autobiography no. 241/35, Z.S.). The Związek Strzelecki had been founded in 1910 in Galicia and became the most important organisational base for the Polish Legion in the Austrian Army under Józef Piłsudski. In the interwar period the organisation was closely connected with the political camp of Józef Piłsudski and the Ministry of Military Affairs. In Ukrainian view, it was the most important Polish nationalist organisation in rural Eastern Galicia and was seen with strong hostility; Tadeusz Bogalecki, 'Związek Strzelecki a problem ukraiński w Drugiej Rzeczypospolitej', in Zbigniew Karpus, Waldemar Rezmer, and Emilian Wiszka (eds.), Polska i Ukraina - sojusz 1920 roku i jego następstwa. Materiaty z konferencji naukowej, Toruń 16-18 listopada 1995 r. (Toruń, 1997), 473-84.

${ }^{66}$ Chałasiński, Młode pokolenie chłopów, ii, 136 (autobiography no. 1107/151, ZMW). See also the report of an activist of the Katolickie Stowarzyszenie Młodzieży (Catholic Youth Association) from a village near Gródek Jagielloński with a similar story, ibidem, 136 f. (autobiography no. 538/197, K.S.M.). 
In his view, the weakness resulted from the social-cultural division into chtop and pan. ${ }^{67}$

Several of the autobiographies that he cites confirm such a view. A young villager from the district of Czortków observed that the social distance between Polish peasants and members of the Polish educated strata was larger than in the Ukrainian case. He saw here a problem in the Polish form of address pan that contained the heritage of the times of serfdom and that the villagers in relation with members of the intelligentsia often used pan najjaśniejszy ('Most Serene Lord') that contained such a meaning in an even stronger way. ${ }^{68}$ The author of a report from Gródek Jagielloński (Ukr. Gorodok) district complained that half of the Poles in his village were "Poles only according to church register", but in reality they were Ukrainians. Asked for the reason of his attitude such a person would answer: "What kind of Pole I am, a Pole is a bourgeois". These Poles would also attend meetings in the Ukrainian Prosvita reading room. The author himself explained that he only started to feel as Pole when he attended school. Also the Polish language had been foreign to him. ${ }^{69}$

On the one hand radical Ukrainian nationalism was spreading in the villages in Eastern Galicia during the interwar period. On the other hand, many villagers kept far away from strong national selfidentification. Traditionally, belonging to the Latin rite was identified with Polishness. Many eastern Galician villagers who belonged to the Roman-Catholic church, however, did not pay much attention to such an alleged meaning of their religious denomination. In Eastern Galicia, the number of Roman-Catholic churches was relatively small and many villagers who had to go a long way to the next church did attend them only on more important holidays. In the meantime, they often attended Greek-Catholic churches in their villages. Often, this paved the way to losing connections with the Roman-Catholic parish and a final registering of former Roman-Catholic parishioners as members of the Greek-Catholic church. The Polish Roman-Catholic side accused the Greek-Catholic church of 'soul theft'. ${ }^{70}$ A peasant son

${ }^{67}$ Ibidem, $144 \mathrm{f}$.

${ }^{68}$ Ibidem, 145 (autobiography no. 1176/87).

${ }^{69} \mathrm{Ibidem}, 145$ f. (autobiography no. 766/106, Z.S.).

${ }^{70}$ This was the mechanism that Józef Gajek considered to be the most important factor in addition to the linguistic assimilation of Polish-speaking villagers to the Ukrainian majority population, Gajek, Problemy etniczne. 
from a village near Podhajce reported that he started to realise that there were more Poles only at the age of five when his mother took him to Roman-Catholic parish fairs. The Polish language was alien to him. This is how he reports his dialogue with his mother when he saw other Poles at the fair:

- And those, who are they?

- They are lords (panowie).

- And why do they speak Polish and we Ruthenian?

- Because the lords speak in Polish and Polish is spoken also in the church.

- Mum, could we speak in Polish?

- What do you think, they would make fun of us. ${ }^{71}$

However, later he became a Polish patriot.

IV

CONCLUSION

The Polish peasant movement and its peasant concept of Polish nationalism gained strong roots in Western Galicia but it remained weak in Eastern Galicia. In Eastern Galicia it did not spread before WWI and did so only to a limited degree in the interwar period. Polish peasant nationalism had support among the Polish settlers. They exposed a strong Polish identity that allowed them to demand support and protection from the Polish government. But they were often in a difficult position both for economic reasons and because of the hostile attitude of their Ukrainian neighbours. This was different for the indigenous Roman-Catholic and/or Polish speaking peasants. Their social role as peasants continued to form a strong link to the Ukrainians and to alienate them from Polish identity. Clearly, their assimilation towards a Ukrainian identity continued in the interwar period while this does not seem to have been an option for the settlers. As Chałasiński's analysis suggests, assimilation might have rather increased during the 1930s when tensions in the countryside rose and more radical attitudes spread among the rural population because of difficult economic conditions and a way of rule that the peasant movement denounced as a return of szlachetczyzna.

${ }^{71}$ Chałasiński, Młode pokolenie chtopów, ii, 146 f. (autobiography no. 371/55, Z.S.). 